\title{
PnBA-b-PNIPAM-b-PDMAEA Thermo-Responsive Triblock Terpolymers and Their Quaternized Analogs as Gene and Drug Delivery Vectors
}

\author{
Athanasios Skandalis (D, Dimitrios Selianitis and Stergios Pispas * (D) \\ Theoretical and Physical Chemistry Institute, National Hellenic Research Foundation, 48 Vassileos \\ Constantinou Avenue, 11635 Athens, Greece; thanos.skan@gmail.com (A.S.); dselianitis@eie.gr (D.S.) \\ * Correspondence: pispas@eie.gr
}

Citation: Skandalis, A.; Selianitis, D.; Pispas, S. PnBA-b-PNIPAM-bPDMAEA Thermo-Responsive Triblock Terpolymers and Their Quaternized Analogs as Gene and Drug Delivery Vectors. Polymers 2021, 13, 2361. https://doi.org/10.3390/ polym13142361

Academic Editor: Marek Kowalczuk

Received: 30 June 2021

Accepted: 16 July 2021

Published: 19 July 2021

Publisher's Note: MDPI stays neutral with regard to jurisdictional claims in published maps and institutional affiliations.

Copyright: (c) 2021 by the authors. Licensee MDPI, Basel, Switzerland. This article is an open access article distributed under the terms and conditions of the Creative Commons Attribution (CC BY) license (https:/ / creativecommons.org/licenses/by/ $4.0 /)$.

\begin{abstract}
In this work, the ability of thermo-responsive poly [butyl acrylate-b-N-isopropylacrylamide-b2-(dimethylamino) ethyl acrylate] (PnBA-b-PNIPAM-b-PDMAEA) triblock terpolymer self-assemblies, as well as of their quaternized analogs (PnBA-b-PNIPAM-b-QPDMAEA), to form polyplexes with DNA through electrostatic interactions was examined. Terpolymer/DNA polyplexes were prepared in three different amine over phosphate group ratios (N/P), and linear DNA with a 2000 base pair length was used. In aqueous solutions, the terpolymers formed aggregates of micelles with mixed PNIPAM/(Q)PDMAEA coronas and PnBA cores. The PnBA-b-PNIPAM-b-PDMAEA terpolymers' micellar aggregates were also examined as carriers for the model hydrophobic drug curcumin (CUR). The complexation ability of the terpolymer with DNA was studied by UV-Vis spectroscopy and fluorescence spectroscopy by investigating ethidium bromide quenching. Fluorescence was also used for the determination of the intrinsic fluorescence of the CUR-loaded micellar aggregates. The structural characteristics of the polyplexes and the CUR-loaded aggregates were investigated by dynamic and electrophoretic light scattering techniques. Polyplexes were found to structurally respond to changes in solution temperature and ionic strength, while the intrinsic fluorescence of encapsulated CUR was increased at temperatures above ambient.
\end{abstract}

Keywords: $\mathrm{ABC}$ triblock terpolymers; stimuli-responsive polymers; polyplexes; drug delivery; bioimaging

\section{Introduction}

Gene therapy has gained significant scientific attention for the treatment of diseases that arise from genetic abnormalities [1-3]. The presence of an effective vector that will carry out the efficient delivery of the genetic material through the cell membrane is a prerequisite $[1,4,5]$. There have been reported two major categories of gene delivery vectors, the viral and the nonviral, each one with its respective advantages and disadvantages [4,6].

Viral-mediated gene delivery systems [2,7] include, among others, adenoviruses and retroviruses and exhibit high transfection efficiency. However, viral gene delivery systems demonstrate limited carrying capacity, immunogenicity toxicity and high cost.

The above-mentioned limitations can be overcome by the utilization of synthetic, nonviral gene delivery vectors as an appealing alternative. Such vectors interact electrostatically with the DNA and must have the ability to condense the DNA, be not immunogenic and toxic, promote cellular uptake and protect DNA from degradation. Cationic polymers [8,9], along with lipids [10-13], have emerged as the most promising nonviral gene delivery vectors. The most used cationic polymers for gene delivery applications are polyethyleneimine (PEI) $[3,14]$, poly(L-lysine) (PLL) [15,16], poly(ethylene glycol) bis (amine) [17,18], poly (2-dimethylamino ethyl methacrylate) (PDMAEMA) [19-21] and poly (2-dimethylamino ethyl acrylate) (PDMAEA) [22,23]. The complexes of cationic polymers with DNA are widely known as polyplexes. 
Stimuli-responsive polymers are promising candidates for gene delivery applications, due to their unique ability to adapt to changes in their environment after the application of external stimuli $[24,25]$. Temperature-responsive polymers demonstrate changes in their conformation/hydration state upon the application of temperature variations. PNIPAM [26-28], probably the most famous and the most-well studied thermo-responsive polymer, exhibits hydrophilic behavior at room temperature and has a lower critical solution temperature (LCST) at approximately $32{ }^{\circ} \mathrm{C}$, above which it becomes less hydrophilic. The biocompatibility, along with its LCST being close to the human body temperature, make PNIPAM an attractive polymer for gene delivery applications [29-33]. Upon heating above the LCST, the PNIPAM chains at the periphery of the polyplexes shrink, leading to increased protection of the DNA against enzymatic degradation. Moreover, the enhanced hydrophobicity without complete dehydration can result in improved transfection efficiency and cellular uptake [34-36].

Amphiphilic block copolymer micelles are widely used as nanocarriers for the encapsulation and delivery of hydrophobic drugs as they seek to avoid possible side effects, decrease drug degradation after administration and enhance the bioavailability of the drug [37-39]. Curcumin (CUR) is a hydrophobic polyphenol compound that has gained significant attention due to its low cytotoxicity, anticancer effects and anti-inflammatory properties [40-43].

The aim of this work was the physicochemical investigation of the capability of PnBA-b-PNIPAM-b-PDMAEA terpolymers and of their quaternized analogs, PnBA-bPNIPAM-QPDMAEA, to form complexes with DNA. Furthermore, the potential of the initial PnBA-b-PNIPAM-b-PDMAEA terpolymers to be utilized as carriers for the encapsulation of the hydrophobic model drug CUR for potential bioimaging purposes (due to CUR's intrinsic fluorescence) was also examined, making use of the hydrophobic interactions with PnBA blocks. The ABC-type triblocks are composed of one hydrophobic PnBA block, one temperature-responsive PNIPAM block and one weak cationic polyelectrolyte PDMAEA block, which is converted into a strong cationic polyelectrolyte with permanent positive charges after post-polymerization functionalization with methyl iodide. In aqueous solutions, the terpolymers self-assemble in spherical micelles with PnBA cores and mixed PNIPAM/(Q)PDMAEA coronas and exhibit aggregation behavior due to secondary interactions, which are weaker in the case of the quaternized terpolymers. Further aggregation takes place upon heating above the LCST of PNIPAM because of the change in its hydrophobicity and the shrinkage of its chains. The complexation of the terpolymers micellar aggregates with DNA is possible through electrostatic interactions between the positive charges of the (Q)PDMAEA and the negative charges of the DNA.

\section{Materials and Methods}

\subsection{Materials}

Deoxyribonucleic acid (DNA) sodium salt from salmon testes ( $2000 \mathrm{bp})$ was obtained from Sigma-Aldrich (Athens, Greece). Curcumin was obtained from Merck (Athens, Greece). Ethidium bromide, sodium chloride and all other reagents were obtained from Sigma-Aldrich and used as received.

\subsection{Triblock Terpolymer Synthesis}

PnBA-b-PNIPAM-b-PDMAEA triblock terpolymers were synthesized by sequential RAFT polymerization using AIBN as the radical initiator, 2-(dodecylthiocarbonothioylthio)2-methylpropionic acid as the chain transfer agent and 1,4-dioxane as the polymerization solvent. The conversion of PnBA-b-PNIPAM-b-PDMAEA triblock terpolymers into PnBA-b-PNIPAM-b-QPDMAEA strong cationic polyelectrolytes was achieved by a typical quaternization reaction in THF, using $\mathrm{CH}_{3} \mathrm{I}$ as the quaternizing agent.

More details about the synthetic procedure, the quaternization process, molecular characterization and aqueous solution properties of the terpolymers can be found in our previous work [44]. The chemical structures of PnBA-b-PNIPAM-b-PDMAEA and PnBA-b- 
PNIPAM-b-QPDMAEA triblock terpolymers are presented in Scheme 1a,b, respectively, and their molecular characteristics can be found in Table 1.

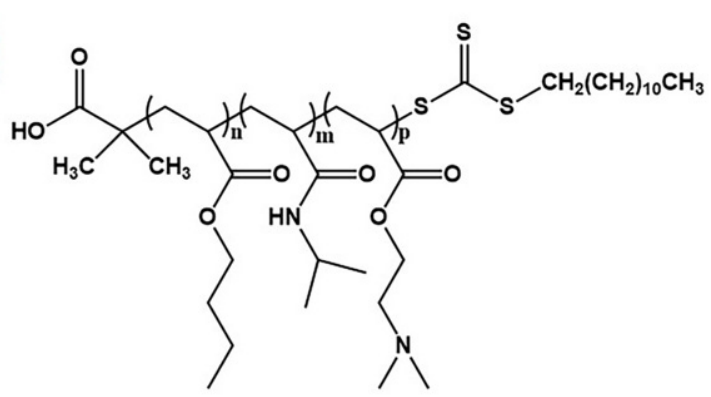

(a)

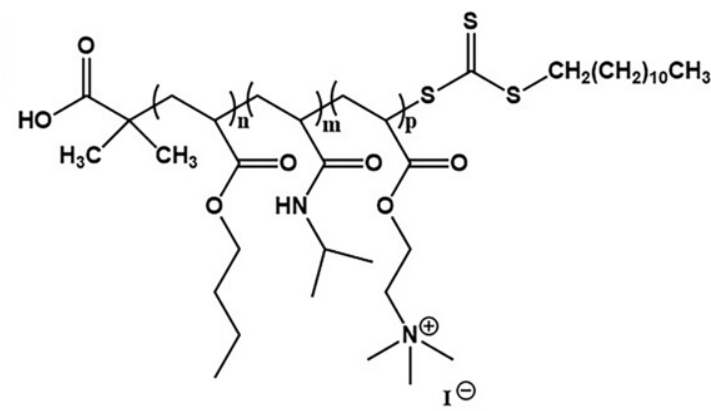

(b)

Scheme 1. Chemical structure of (a) PnBA-b-PNIPAM-b-PDMAEA and (b) PnBA-b-PNIPAM-b-QPDMAEA triblock terpolymers.

Table 1. Molecular characteristics of PnBA-b-PNIPAM-b-(Q)PDMAEA terpolymers.

\begin{tabular}{|c|c|c|c|}
\hline Sample & $\begin{array}{l}\mathrm{M}_{\mathrm{w}}^{\mathrm{a}}\left(10^{-4}\right) \\
\left(\mathrm{g} \mathrm{mol}^{-1}\right)\end{array}$ & $\mathbf{M}_{\mathbf{w}} / \mathbf{M}_{\mathbf{n}}{ }^{\mathbf{a}}$ & $\begin{array}{c}\text { Composition }^{b}(\% \text { wt) } \\
\text { PnBA/PNIPAM/(Q)PDMAEA }\end{array}$ \\
\hline PnBA $_{39}-b-$ PNIPAM $_{87}-b$-PDMAEA 17 & 1.82 & 1.25 & $28 / 59 / 13$ \\
\hline PnBA $_{39}-b-$ PNIPAM $_{87}-b-$ PDMAEA $_{35}$ & 2.40 & 1.27 & $25 / 54 / 21$ \\
\hline PnBA $_{39}-b$-PNIPAM $87-b$-QPDMAEA 17 & $2.05^{c}$ & - & $26 / 51 / 23$ \\
\hline $\mathrm{PnBA}_{39}-b$-PNIPAM ${ }_{87}-b$-QPDMAEA 35 & $2.90^{\mathrm{c}}$ & - & $21 / 45 / 34$ \\
\hline
\end{tabular}

${ }^{\mathrm{a}}$ Determined by SEC, ${ }^{\mathrm{b}}$ Determined by ${ }^{1} \mathrm{H}-\mathrm{NMR},{ }^{\mathrm{c}}$ Calculated for $100 \%$ conversion.

\subsection{Polyplex Formation}

The terpolymer/DNA polyplexes were formed by mixing terpolymer solution $\left(5 \times 10^{-4} \mathrm{~g}\right.$ $\mathrm{mL}^{-1}$ in $\left.0.01 \mathrm{M} \mathrm{NaCl}\right)$ and DNA solution $\left(3.3 \times 10^{-4} \mathrm{~g} \mathrm{~mL}^{-1}\right.$ in $\left.0.01 \mathrm{M} \mathrm{NaCl}\right)$ under gentle stirring at ambient conditions. The volume of the terpolymer solution was predefined and the corresponding volume of DNA solution was added for all N/P ratios formed. The final volume of the prepared mixed solutions was adjusted at $10 \mathrm{~mL}$. The polyplexes were prepared in three different $\mathrm{N} / \mathrm{P}$ ratios $(0.5,1.0$ and 2.0$)$.

\subsection{Preparation of CUR-Loaded Micellar Aggregates}

The procedure followed for the encapsulation of CUR into the triblock terpolymer nanostructures is described below. First, two separate stock solutions of the terpolymer and the drug were prepared in THF. The solutions were left to stand overnight to ensure the complete dissolution of the terpolymer and curcumin. Next, the two solutions were mixed in two different ratios and the mixtures were directly injected into distilled water under vigorous stirring until THF evaporation by heating at $65^{\circ} \mathrm{C}$.

\subsection{Light Scattering}

Dynamic light scattering (DLS) measurements were conducted on an ALV /CGS-3 compact goniometer system (ALVGmbH, Hessen, Germany), equipped with an ALV 5000/EPP multi- $\tau$ digital correlator with 288 channels and an ALV/LSE-5003 light scattering electronics unit for stepper motor drive and limit switch control. A JDS Uniphase $22 \mathrm{~mW} H \mathrm{He}-\mathrm{Ne}$ laser $(\lambda=632.8 \mathrm{~nm})$ was used as the light source. The solutions were filtered through $0.45 \mu \mathrm{m}$ hydrophilic PTFE filters (Millex-LCR from Millipore, Billerica, MA, USA) before measurements. Each solution was measured five times at each angle and temperature and the average was used. The angular and temperature range for the measurements were $30-150^{\circ}$ and $25-55^{\circ} \mathrm{C}$, respectively. The cumulants method and CONTIN software were 
utilized for the analysis of the obtained correlation functions. The size data and figures shown below are from measurements at $90^{\circ}$.

Electrophoretic light scattering (ELS) measurements were performed on a ZetaSizer Nano Series Nano-ZS (Malvern Instruments Ltd., Malvern, UK) equipped with a He-Ne laser beam at a wavelength of $633 \mathrm{~nm}$ and a fixed backscattering angle of $173^{\circ}$. Measurements were conducted at $25^{\circ} \mathrm{C}$ and $45^{\circ} \mathrm{C}$. Data analysis was performed using the Henry correction of the Smoluchowski equation [45], after equilibration at $25^{\circ} \mathrm{C}$ or $45^{\circ} \mathrm{C}$ (depending on the measurement temperature). Reported zeta-potential $\left(\zeta_{\mathrm{p}}\right)$ values are the average of 50 runs.

\subsection{UV-Vis}

UV-V is measurements of the polyplexes were conducted on a Perkin Elmer (Lambda 19) UV-Vis-NIR spectrometer (Waltman, MA, USA) in a wavelength range of 200 to $400 \mathrm{~nm}$. The polyplexes were measured at all three N/P ratios prepared.

\subsection{Fluorescence Spectroscopy}

\subsubsection{Ethidium Bromide Quenching Assay}

The complexation ability of the terpolymers with DNA was investigated by studying the fluorescence of ethidium bromide (EtBr) in the whole N/P ratio range. A DNA solution $\left(1 \times 10^{-4} \mathrm{~g} \mathrm{~mL}^{-1}\right)$ was initially prepared in $0.01 \mathrm{M} \mathrm{NaCl}$, followed by the addition of ethidium bromide $([\mathrm{EtBr}] /[\mathrm{P}]=4)$ to it. The EtBr-containing DNA solution was titrated with a concentrated terpolymer solution starting from $\mathrm{N} / \mathrm{P}=0$ and ending at $\mathrm{N} / \mathrm{P}=8.0$. Fluorescence spectroscopy measurements were carried out for the initial DNA/EtBr solution, as well as after each titration with the polymer solution. Fluorescence spectra were recorded on a Fluorolog-3 Jobin Yvon-Spex spectrofluorometer (model GL3-21). The excitation wavelength for the measurements was $535 \mathrm{~nm}$ and the emission was monitored at $600 \mathrm{~nm}$.

\subsubsection{Fluorescence of CUR-Loaded Aggregates}

The same instrument was used for fluorescence measurements of the CUR-loaded terpolymer aggregates and the excitation wavelength was set at $405 \mathrm{~nm}$.

\section{Results and Discussion}

\subsection{PDMAEMA-b-PNIPAM-b-(Q)PDMAEA/DNA Polyplexes}

The ability of the nanostructures formed by PnBA- $b$-PNIPAM- $b$-PDMAEA and PnBA$b$-PNIPAM- $b$-QPDMAEA triblock terpolymers in aqueous solutions to complex with DNA was investigated. The complexation is achieved through electrostatic interactions between the positively charged amine groups of the terpolymers $(\mathrm{N})$ and the negatively charged phosphoric groups of the DNA $(\mathrm{P})$. The terpolymer/DNA complex solutions were prepared in three different $\mathrm{N} / \mathrm{P}$ ratios $\left(\mathrm{N} / \mathrm{P}=0.5,1.0\right.$ and 2.0) using DNA with $\mathrm{M}_{\mathrm{W}}=2000 \mathrm{bp}$.

The successful formation of the polyplexes was confirmed by UV-Vis spectroscopy measurements. UV-Vis spectra for (a) PnBA- $b$-PNIPAM- $b$-PDMAEA/DNA and (b) PnBA$b$-PNIPAM- $b$-QPDMAEA/DNA polyplexes are presented in Figure 1 . The characteristic peak that corresponds to free DNA appears at $260 \mathrm{~nm}$, while simultaneously a new peak is observed at $225 \mathrm{~nm}$, which corresponds to the complexed DNA. However, this peak is only visible in the case of the quaternized terpolymers (Figure 1b). More specifically, for $\mathrm{N} / \mathrm{P}=0.5$, both peaks are observed (at 225 and at $260 \mathrm{~nm}$ ) and this can be attributed to the existence of both complexed and free DNA in the solution at the same time. 

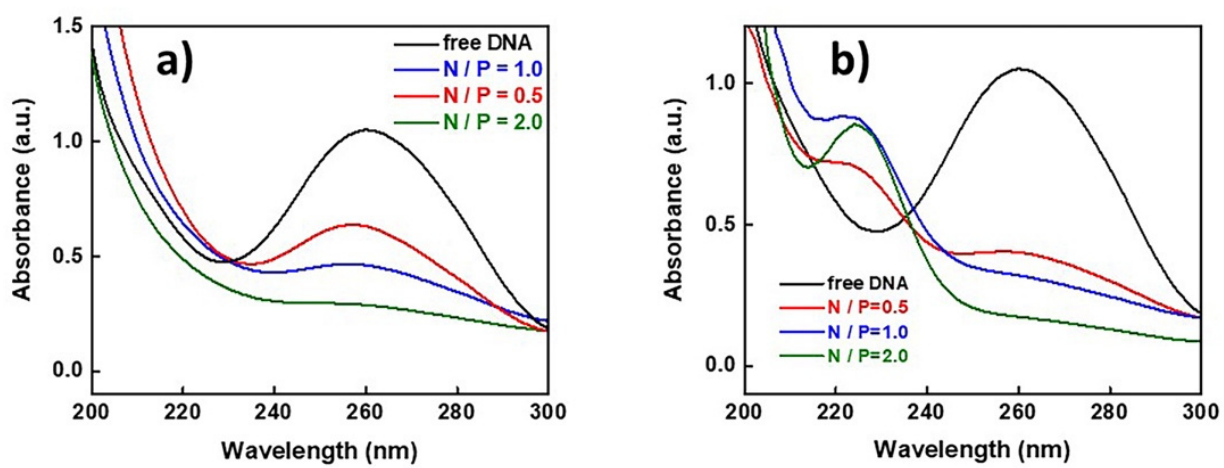

Figure 1. UV-Vis spectra of (a) $\mathrm{PnBA}_{39}-b$-PNIPAM $\mathrm{P}_{7}-b$-PDMAEA 35 /DNA polyplexes and (b) $\mathrm{PnBA}_{39}$ - $b$-PNIPAM $87-b$-QPDMAEA 35 /DNA polyplexes (spectrum of free DNA in black).

As the terpolymer concentration in the solution increases, the peak at $260 \mathrm{~nm}$ disappears and only the one at $260 \mathrm{~nm}$ is visible, meaning that the total amount of DNA participates in the formation of polyplexes. This occurs because the increase in the positive charges in the solution leads to the neutralization of the negative DNA charges.

On the other hand, in the case of PnBA- $b$-PNIPAM- $b$-PDMAEA/DNA polyplexes (Figure 1a), a similar decrease is observed in the height of the free DNA peak as the polymer concentration increases, but the peak at $225 \mathrm{~nm}$ that corresponds to the bonded DNA is not visible. This is an indication that the electrostatic interactions between terpolymer and DNA are significantly more intense when the quaternized terpolymers are used, due to the existence of permanent positive charges.

Ethidium bromide fluorescence quenching assays (Figure 2) support the conclusion that the quaternized terpolymers interact more strongly and more efficiently with DNA molecules forming polyplexes. This is evident through the strongest decrease in relative fluorescence for the $\mathrm{PnBA}_{39}-b$-PNIPAM $87-b$-QPDMAEA 35 polyplexes compared to $\mathrm{PnBA}_{39}$ $b$-PNIPAM ${ }_{87}-b$-PDMAEA 35 ones, at N/P ratios greater than 3 . However, even at an N/P ratio equal to 8 , the relative fluorescence does not drop below 0.7 , indicating that the terpolymer micellar aggregates do not interact sufficiently with DNA, possibly due to their aggregate structure, which hinders terpolymer/DNA interactions because of spatial constraints, including low access of amine/quaternary amine groups by DNA chains in the corona of the terpolymer micellar aggregates.

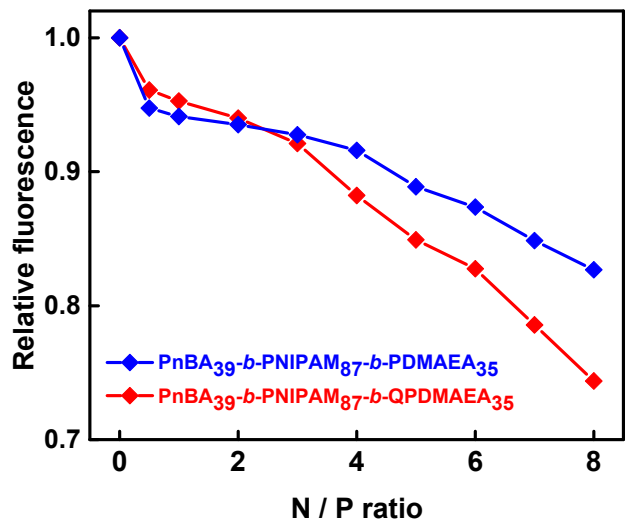

Figure 2. Ethidium bromide fluorescence quenching in $\mathrm{PnBA}_{39}-b$-PNIPAM $87-b$-PDMAEA 35 (blue line) and $\mathrm{PnBA}_{39}-b$-PNIPAM $87-b$-QPDMAEA 35 (red line) polyplexes with DNA.

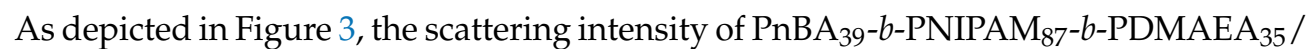
DNA does not exhibit major changes for $\mathrm{N} / \mathrm{P}=0.5$ and $\mathrm{N} / \mathrm{P}=1$ ratios and decreases significantly for $\mathrm{N} / \mathrm{P}=2$, showing that, in this case, particles with smaller mass are present. On the contrary, as far as the size of the polyplexes is concerned, it is observed that at 
$\mathrm{N} / \mathrm{P}=0.5$, there are large aggregates $\left(\mathrm{R}_{\mathrm{h}}=380 \mathrm{~nm}\right.$ approximately $)$ and there is a great size decrease at $\mathrm{N} / \mathrm{P}=1\left(\mathrm{R}_{\mathrm{h}}=170 \mathrm{~nm}\right.$ approximately). This rapid decrease in the size of the polyplexes is attributed to the formation of the smaller aggregates since the concentration of DNA increases and interactions are more efficient. At N/P $=0.5$, the negatively charged phosphate groups are in excess and the formation of stable complexes with the polymeric nanostructures is more difficult. Therefore, the formation of aggregates is favored.
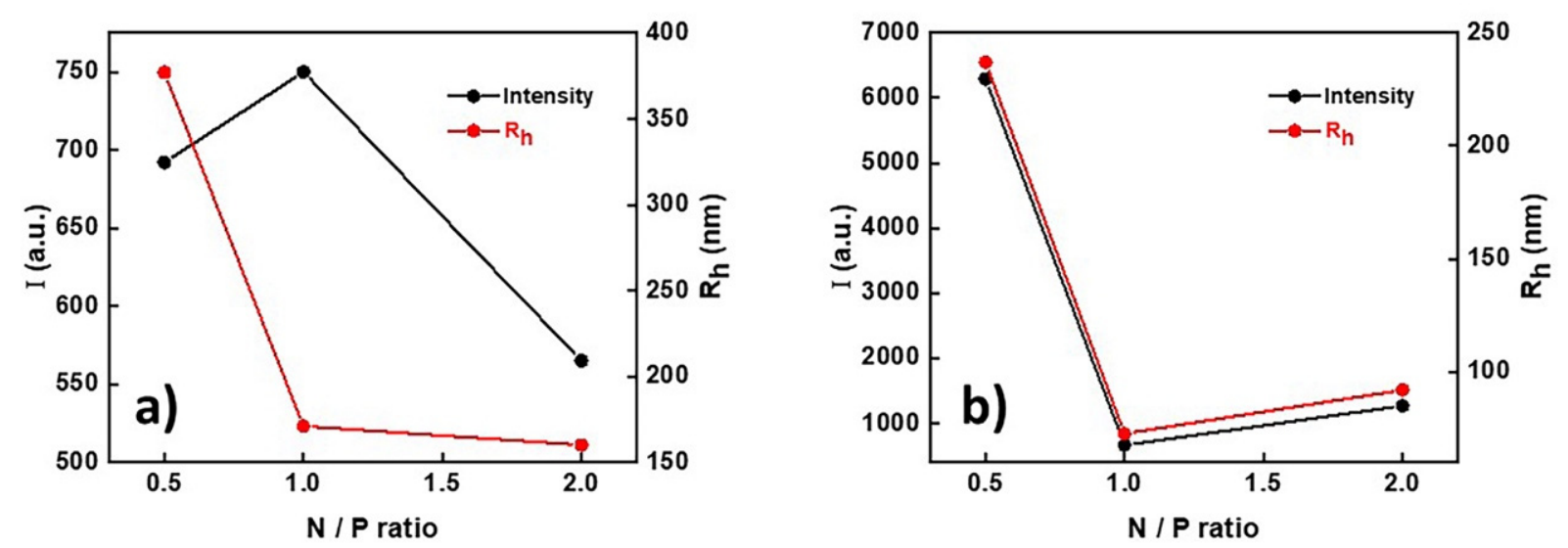

Figure 3. Variations in scattering intensity and $R_{h}$ with N/P ratio for (a) $\mathrm{PnBA}_{39}-b$-PNIPAM $87-b-\mathrm{PDMAEA}_{35} / \mathrm{DNA}$ and (b) $\mathrm{PnBA}_{39}$ - $b$-PNIPAM 87 - $b$-QPDMAEA 35 /DNA polyplexes.

At the ratios where the amine groups of the terpolymer are either in equilibrium or in excess (the size of the polyplexes does not change at $\mathrm{N} / \mathrm{P}=2$ ), it seems that the complexation with DNA is stronger and induces the breaking of the intermicellar aggregates and the formation of more stable structures.

At $\mathrm{PnBA}_{39}-b$-PNIPAM ${ }_{87}-b$-QPDMAEA ${ }_{35} / \mathrm{DNA}^{-}$polyplexes, the scattering intensity shows a rapid decrease from $\mathrm{N} / \mathrm{P}=0.5$ to $\mathrm{N} / \mathrm{P}=1$ and remains practically unchanged for $\mathrm{N} / \mathrm{P}=2$. As mentioned earlier, at $\mathrm{N} / \mathrm{P}=0.5$, the DNA is in excess and the electrostatic interactions are weaker, leading to the formation of aggregates. The size of the polyplexes also shows a rapid decrease from $250 \mathrm{~nm}$ at $\mathrm{N} / \mathrm{P}=0.5$ to $70 \mathrm{~nm}$ at $\mathrm{N} / \mathrm{P}=1$. This decrease is attributed to the formation of smaller intermicellar aggregates in the solution.

At $N / P=2$, there is a small increase in the size of the polyplexes $\left(R_{h}=95 \mathrm{~nm}\right)$. Moreover, it must be highlighted that the electrostatic interactions between the quaternized terpolymers and the DNA are much stronger than the interactions between the nonquaternized ones (amine form) with DNA, due to the existence of more positive charges.

Dynamic and electrophoretic light scattering were also utilized for more detailed investigations of the temperature effect on $\mathrm{PnBA}_{39}-b$-PNIPAM ${ }_{87}-b$-PDMAEA/DNA and PnBA- $b$-PNIPAM ${ }_{87}-b$-QPDMAEA/DNA polyplexes, because of the presence of the thermoresponsive PNIPAM block in the structure of the terpolymers.

The size distribution graphs from DLS measurements for $\mathrm{PnBA}_{39}-b-\mathrm{PNIPAM}_{87}-b-$ PDMAEA35/DNA $(a, b)$ and PnBA $_{39}-b$-PNIPAM 87 - $b$-QPDMAEA ${ }_{35} /$ DNA (c, d) polyplexes at $25^{\circ} \mathrm{C}(\mathrm{a}, \mathrm{c})$ and at $55^{\circ} \mathrm{C}(\mathrm{b}, \mathrm{d})$ are presented in Figure 4. Monomodal size distributions are observed in all cases. For $\mathrm{PnBA}_{39}-b$-PNIPAM ${ }_{87}-b$-PDMAEA $35 /$ DNA polyplexes at $25^{\circ} \mathrm{C}$ (Figure 4a), the size distribution becomes narrower as the polymer concentration in the solution increases. Similar behavior is observed for $\mathrm{PnBA}_{39}-b$-PNIPAM $_{87}-b$-QPDMAEA $35 / D N A$ polyplexes at $25{ }^{\circ} \mathrm{C}$ (Figure 4c). 

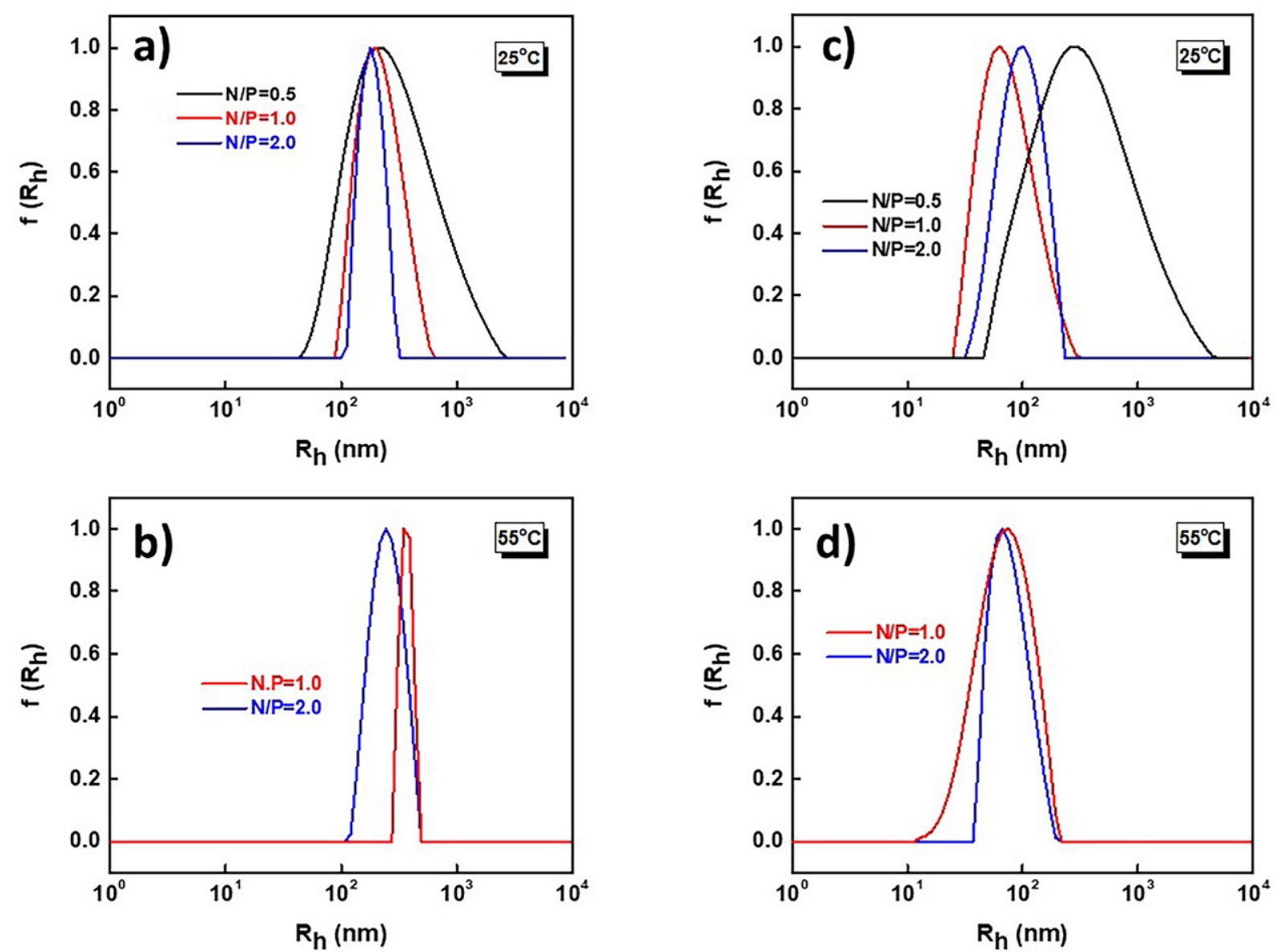

Figure 4. Size distributions of $\mathrm{PnBA}_{39}-b-\mathrm{PNIPAM}_{87}-b-\mathrm{PDMAEA}_{35} / \mathrm{DNA}(\mathbf{a}, \mathbf{b})$ and $\mathrm{PnBA}_{39}-b-\mathrm{PNIPAM}_{87}-b-\mathrm{QPDMAEA}_{35} / \mathrm{DNA}$ (c,d) polyplexes at $25^{\circ} \mathrm{C}(\mathbf{a}, \mathbf{c})$ and at $55^{\circ} \mathrm{C}(\mathbf{b}, \mathbf{d})$.

At $55{ }^{\circ} \mathrm{C}$, precipitation phenomena took place for both complexes involving the nonquaternized and the quaternized terpolymers. For the other N/P ratios, the solutions remained stable, and the size distributions remained monomodal. In the case of $\mathrm{PnBA}_{39^{-}}$

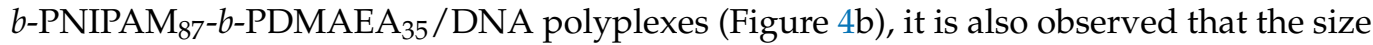
distributions become narrower as the polymer concentration increases, while for $\mathrm{PnBA}_{39}-b$ PNIPAM $_{87}-b$-QPDMAEA ${ }_{35} /$ DNA polyplexes (Figure $4 d$ ), there are no significant changes.

Figure 5 shows the dependence of the scattering intensity and hydrodynamic diameter of the terpolymer/DNA polyplexes on temperature. A constant increase in the scattering intensity (increase in the mass of the particles) is seen for $\mathrm{PnBA}_{39}-b$ - $\mathrm{PNIPAM}_{87^{-}}$ $b$-PDMAEA $35 /$ DNA polyplexes at $\mathrm{N} / \mathrm{P}=1$ (Figure $5 \mathrm{a}$ ) and up to $45^{\circ} \mathrm{C}$. In the range of $45-55{ }^{\circ} \mathrm{C}$, a plateau is reached. The $\mathrm{R}_{\mathrm{h}}$ follows a similar pattern and increases as the temperature rises up to $35^{\circ} \mathrm{C}$, remains practically unchanged between 35 and $50^{\circ} \mathrm{C}$ and increases again from 50 to $55^{\circ} \mathrm{C}$. This behavior shows that as the temperature increases, which means that PNIPAM blocks becomes less hydrophilic and shrink, the polyplexes tend to form larger aggregates. Importantly, the response of the terpolymers to temperature variations is maintained after their complexation with the DNA. Similar behavior is observed for $\mathrm{N} / \mathrm{P}=2$ (Figure $5 \mathrm{~b}$ ). 

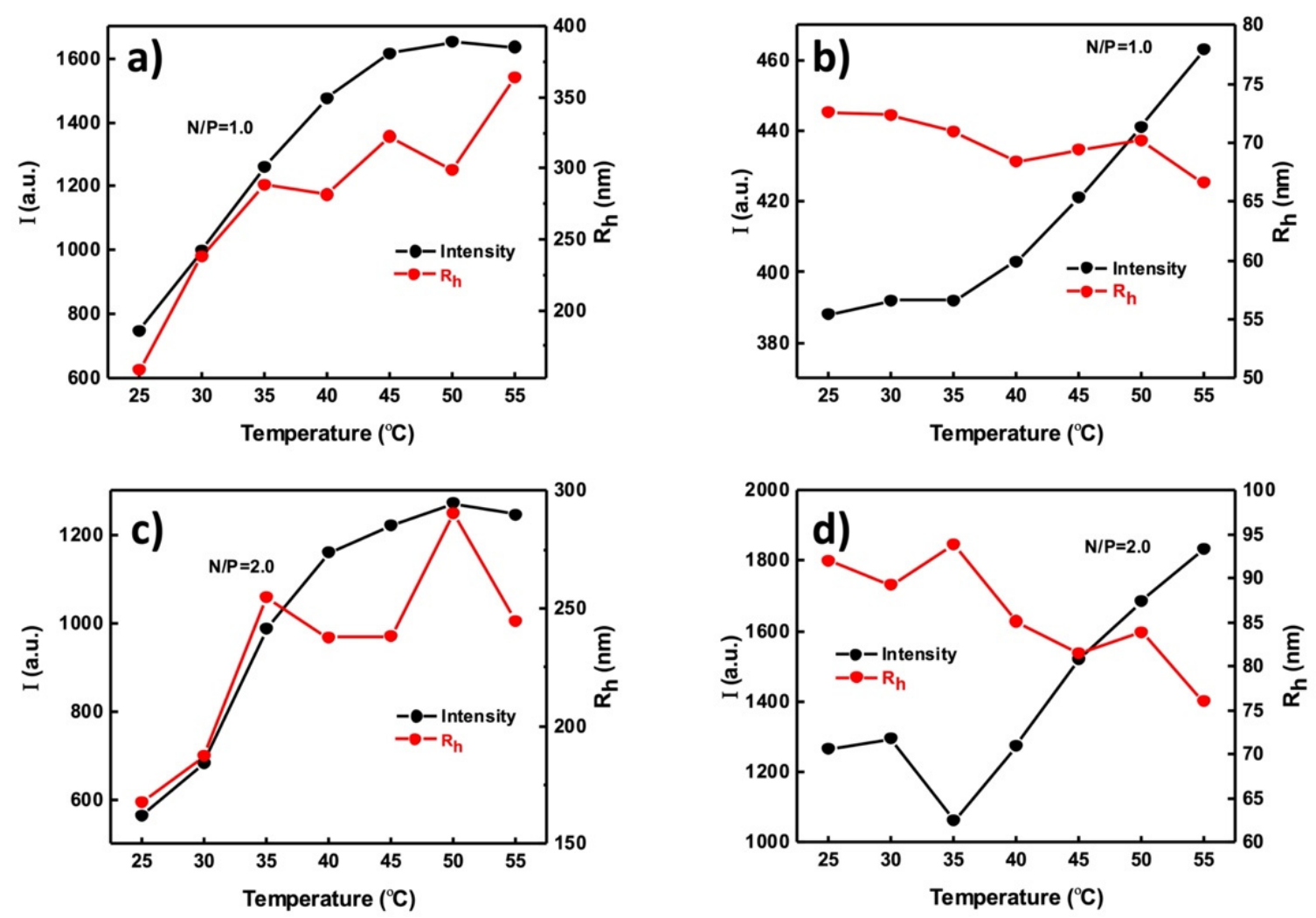

Figure 5. Scattering intensity and $R_{h}$ as a function of temperature for $\mathrm{PnBA}_{39}-b-\mathrm{PNIPAM}_{87}-b-\mathrm{PDMAEA}_{35} / \mathrm{DNA}$ polyplexes at (a) $\mathrm{N} / \mathrm{P}=1.0$ and $(\mathbf{b}) \mathrm{N} / \mathrm{P}=2.0$ and $\mathrm{PnBA}_{39}-b-\mathrm{PNIPAM}_{87}-b-\mathrm{QPDMAEA}_{35} / \mathrm{DNA}$ polyplexes at $(\mathbf{c}) \mathrm{N} / \mathrm{P}=1.0$ and $(\mathbf{d}) \mathrm{N} / \mathrm{P}=2.0$.

For the quaternized terpolymers/DNA polyplexes at N/P $=1$ (Figure $5 \mathrm{c}$ ), an increase can be observed in the scattering intensity from $35^{\circ} \mathrm{C}$ and above, but at a much lower scale than at $\mathrm{PnBA}_{39}-b$-PNIPAM $87-b$-PDMAEA 35 /DNA polyplexes, while the changes in $\mathrm{R}_{\mathrm{h}}$ are insignificant. This means that as the temperature increases and the PNIPAM block shrinks, disassociation of the aggregates (if they exist) or shrinkage of the polymeric micelles may take place. Similar results are obtained for $\mathrm{N} / \mathrm{P}=2$, with the changes in the size of the polyplexes being slightly larger, indicating that the polymer/DNA ratio is a very important factor regarding the response of the polyplexes to temperature variations.

The surface charge of the polyplexes, at all N/P ratios, was investigated by electrophoretic light scattering measurements at $25^{\circ} \mathrm{C}$ and at $45^{\circ} \mathrm{C}$ (Figure 6). For PnBA $39-b$ $\mathrm{PNIPAM}_{87}-b$-PDMAEA ${ }_{35} /$ DNA at $25^{\circ} \mathrm{C}$ (Figure $6 \mathrm{a}$ ), the $\zeta$-potential values are negative at all $\mathrm{N} / \mathrm{P}$ ratios, meaning that there is uncomplexed DNA in the solution. The explanation behind this observation is that the terpolymers are partially protonated and, for this reason, the electrostatic interactions are weak. At $45^{\circ} \mathrm{C}$, a temperature above the LCST of PNIPAM, the largest change is observed at $\mathrm{N} / \mathrm{P}=0.5$, where the solution is not colloidally stable. For the remaining $\mathrm{N} / \mathrm{P}$ ratios, there were no important changes.

As far as the $\mathrm{PnBA}_{39}-b$-PNIPAM ${ }_{87}-b$-QPDMAEA $35 /$ DNA polyplexes at $25{ }^{\circ} \mathrm{C}$ are concerned (Figure $6 \mathrm{~b}$ ), the $\zeta$-potential values are negative for $\mathrm{N} / \mathrm{P}=0.5$, due to the existence of free DNA in the solution. At $\mathrm{N} / \mathrm{P}=1$ and $\mathrm{N} / \mathrm{P}=2$ ratios, where the quaternized amine groups of the QPDMAEA cationic block are either in equilibrium or in excess in comparison to the negatively charged phosphate groups of DNA, the $\zeta$-potential values are positive. This may indicate either the existence of micelles that have not complexed with the DNA, or that each DNA molecule interacts with more than one micelle, creating aggregates the outer parts of which carry positive charges. The latter seems to be the most probable scenario. 

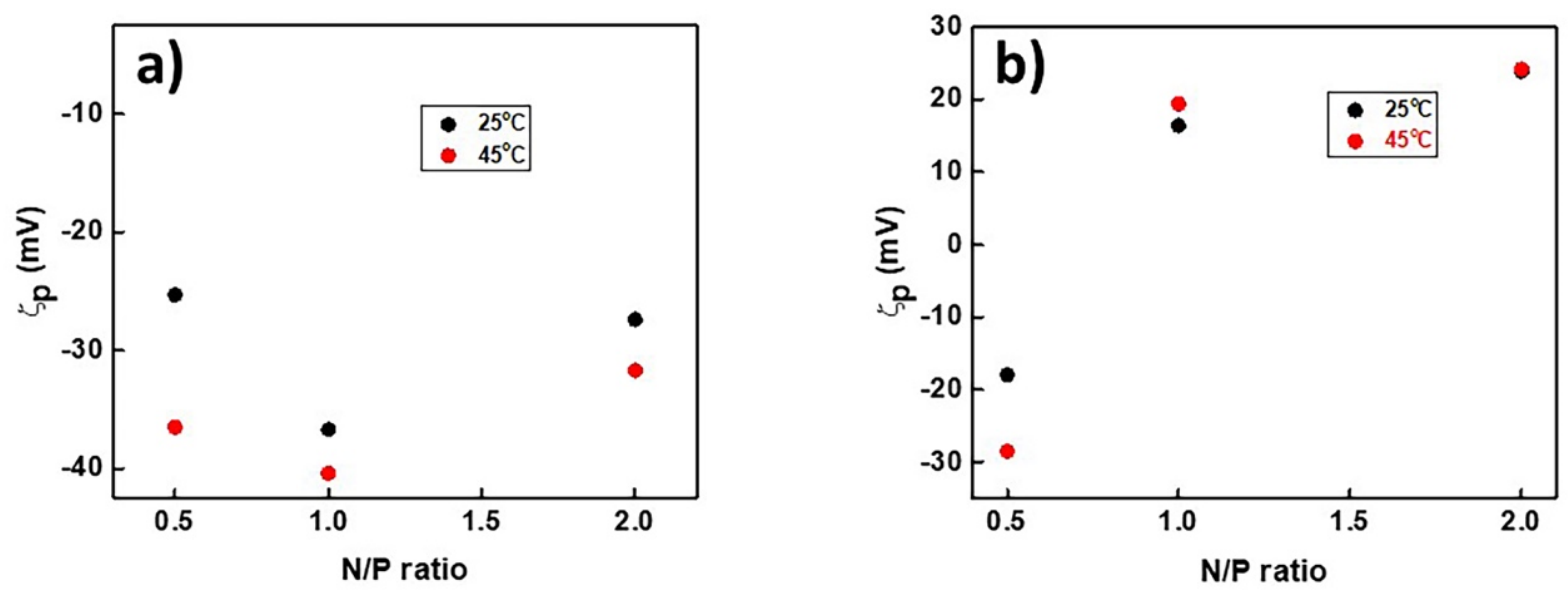

Figure 6. Variation in $\zeta$-potential with N/P ratio for $\mathrm{PnBA}_{39}-b$-PNIPAM $87-b-\mathrm{PDMAEA}_{35} / \mathrm{DNA}(\mathbf{a})$ and $\mathrm{PnBA}_{39}-b-\mathrm{PNIPAM}_{87}-$ $b$-QPDMAEA $35 /$ DNA (b) polyplexes at $25^{\circ} \mathrm{C}$ and at $45^{\circ} \mathrm{C}$.

The effect of ionic strength in the terpolymer/DNA polyplexes was also studied, as it is a very important parameter for the efficacy of a cationic polymer as nonviral gene delivery system. Figure 7 depicts the changes in the scattering intensity and hydrodynamic diameter of the polyplexes as a function of ionic strength at $\mathrm{N} / \mathrm{P}=1$ and $\mathrm{N} / \mathrm{P}=2$ ratios.
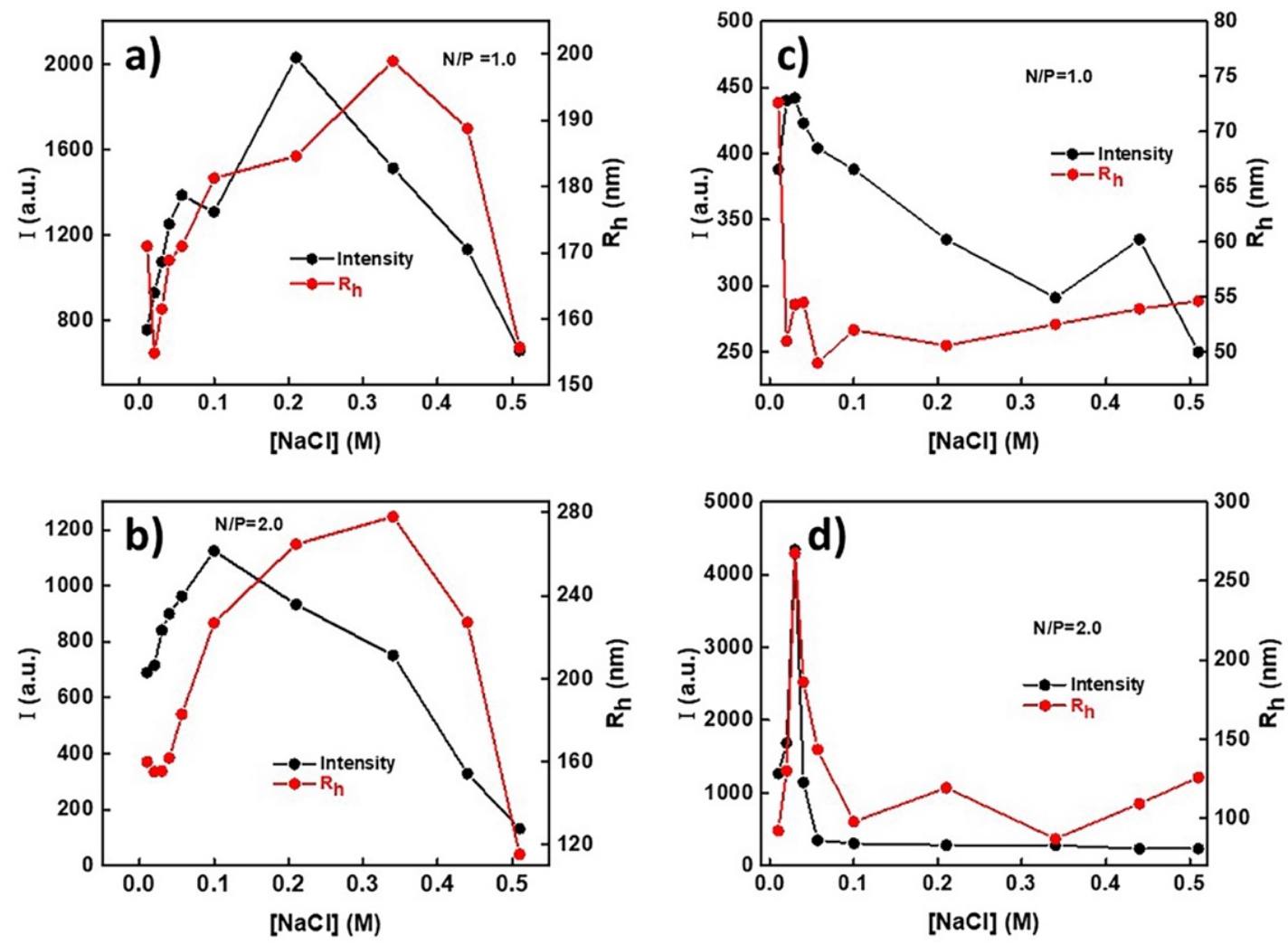

Figure 7. Scattering intensity and $\mathrm{R}_{\mathrm{h}}$ as a function of ionic strength for $\mathrm{PnBA}_{39}-b-\mathrm{PNIPAM}_{87}-b-\mathrm{PDMAEA}_{35} / \mathrm{DNA}$ polyplexes

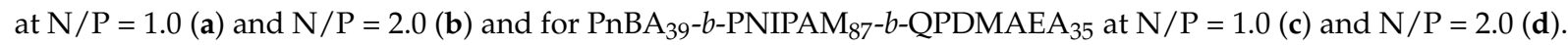

For $\mathrm{PnBA}_{39}-b$-PNIPAM $87-b$-PDMAEA $35 /$ DNA polyplexes at N/P $=1$ (Figure $7 \mathrm{a}$ ), the scattering intensity increases $\mathrm{C}_{\mathrm{NaCl}}=0.2 \mathrm{M}$ and decreases for higher salt concentrations. The initial increase is translated into an increase in the mass of the polyplexes, which continues until their disintegration, where the decrease in the scattering intensity begins, showing that the polyplexes are not stable at higher salt concentrations. The $R_{h}$ of the 
polyplexes exhibits a similar trend. It increases till $\mathrm{C}_{\mathrm{NaCl}}=0.32 \mathrm{M}$ and decreases thereafter. A similar pattern is observed for the polyplexes formed at N/P $=2$ (Figure $7 \mathrm{~b}$ ).

$\mathrm{PnBA}_{39}-b$-PNIPAM ${ }_{87}-b$-QPDMAEA 35 /DNA polyplexes exhibit different behavior as the salt concentration increases. At the ratio $\mathrm{N} / \mathrm{P}=1$ (Figure $7 \mathrm{c}$ ), the scattering intensity decreases in all cases, but at a much lower rate than the PnBA $_{39}-b$-PNIPAM ${ }_{87}$ -

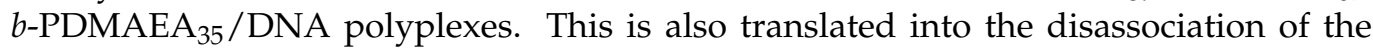
complexes and they are not stable upon an ionic strength increase. The $R_{h}$ decreases from approx. $72 \mathrm{~nm}$ to approx. $52 \mathrm{~nm}$ with the first addition of salt and remains practically unchanged within the remaining ionic strength range studied.

At $\mathrm{N} / \mathrm{P}=2$ (Figure 7d), an initial increase is observed in the scattering intensity till $\mathrm{C}_{\mathrm{NaCl}}=0.04 \mathrm{M}$, followed by a significant decrease till $\mathrm{C}_{\mathrm{NaCl}}=0.065 \mathrm{M}$, and the intensity remains constant at higher ionic strength values. The $R_{h}$ behavior follows the same pattern as the scattering intensity. This shows that dissociation of the polyplexes takes place even at relatively low salt concentrations.

After evaluation of all the results obtained from the physicochemical characterization of the terpolymer/DNA complexes, the complexation process is illustrated in Scheme 2. The effect of temperature is much more visible in the case of PnBA- $b$-PNIPAM$b$-PDMAEA/DNA complexes, where the electrostatic interactions are weaker.
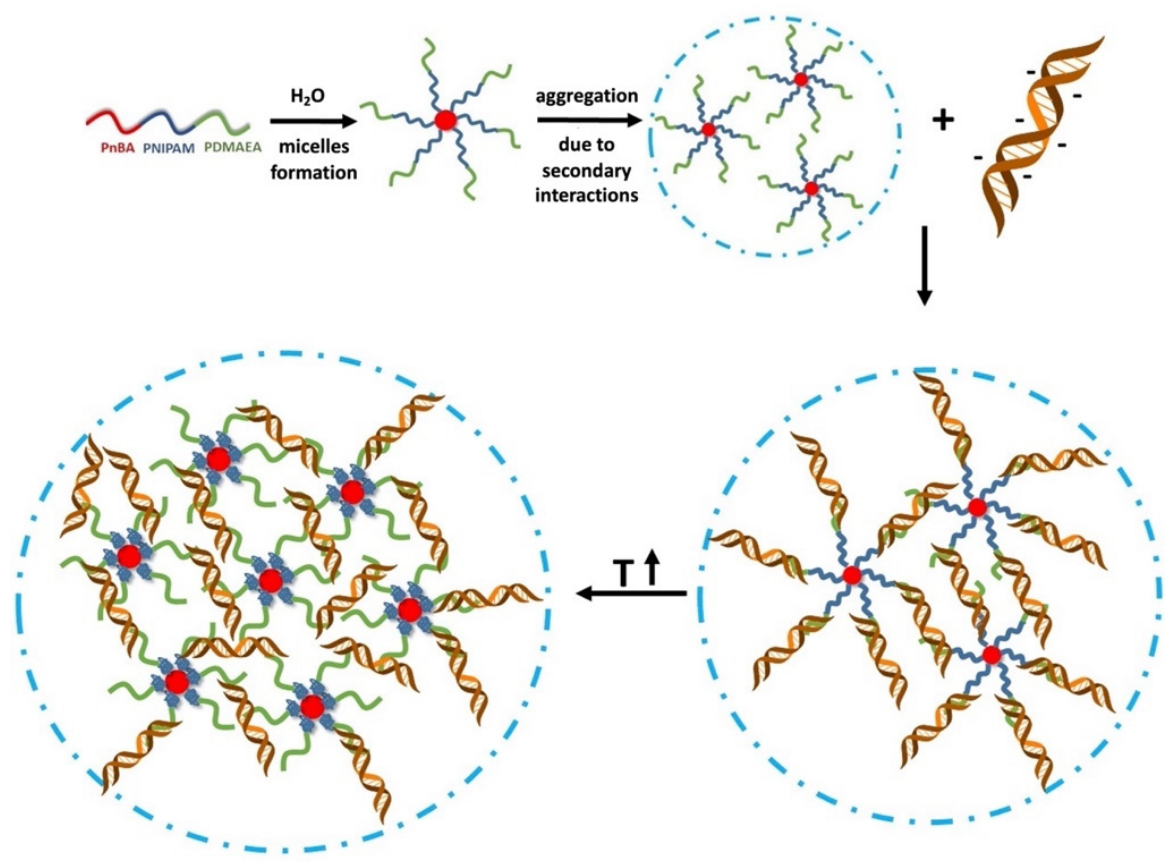

Scheme 2. Schematic illustration of the complexation process of PnBA-b-PNIPAM-b-(Q)PDMAEA triblock terpolymers with DNA.

\subsection{Encapsulation of CUR in the PnBA-b-PNIPAM-b-PDMAEA Polymeric Micellar Aggregates}

The capability of PnBA-b-PNIPAM-b-PDMAEA terpolymers to act as drug delivery carriers was also investigated by encapsulating curcumin (a model hydrophobic drug). Curcumin is considered an anticancer and anti-inflammatory drug with increased hydrophobicity $[41,42]$. Dynamic light scattering and fluorescence spectroscopy measurements were carried out in order to determine the successful encapsulation of curcumin in the polymeric micelles and to specify the properties that curcumin imparts to the polymeric system. CURloaded micellar aggregates with $10 \%$ and $20 \% w / w$ targeted entrapment levels (relative to the hydrophobic PnBA content) for $\mathrm{PnBA}_{39}-b$-PNIPAM $87-b$-PDMAEA 35 copolymer were prepared according to the protocol described above. UV-Vis determinations, utilizing a calibration curve, showed that the $10 \% w / w$ formulation actually resulted in $27 \%$ drug loading efficiency with a drug loading of $0.7 \%$, while for the $20 \% w / w$ formulation, the 
values were $59 \%$ and $1.5 \%$, respectively. Despite the rather low CUR entrapment, DLS measurements of the loaded terpolymer nanostructure were recorded at $25^{\circ} \mathrm{C}, 45^{\circ} \mathrm{C}$ and at a $90^{\circ}$ measuring angle. The fluorescence spectroscopy study was accomplished in the same temperature range. Figure 8 illustrates comparative plots of the size distributions of CUR-loaded PnBA 39 -b-PNIPAM 87 -b-PDMAEA 35 nanostructures.
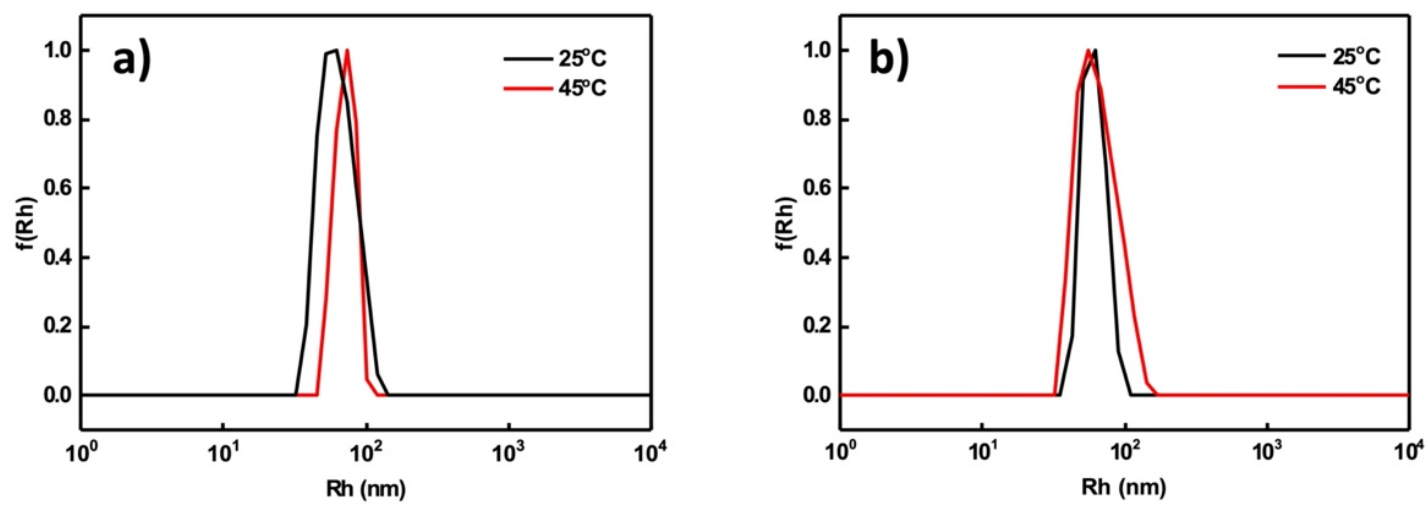

Figure 8. Comparative size distributions graphs from DLS measurements for CUR-loaded PnBA $39-b-\mathrm{PNIPAM}_{87}-b-$ PDMAEA $_{35}$ micelles as a function of temperature for $10 \%$ CUR (a) and $20 \%$ wt CUR (b).

The size distributions from DLS measurements presented in Figure 8 reveal that the addition of curcumin (10 wt\% and $20 \mathrm{wt} \%$ relative to the hydrophobic PnBA block) causes a slight decrease in the dimensions of the polymeric micelles, which is accompanied by a significant reduction in the polydispersity index. This observation proves that the entrapment of curcumin significantly improves the self-organization of the drug-loaded nanoparticles and may denote that the hydrophobic interactions created between the copolymer and the drug facilitate the effective encapsulation of CUR into the polymeric micelles. From the results shown in Table 2, it is worth noting that when the temperature was increased, a significant increase occurred in the mass of CUR-loaded nanoparticles, which indicates the formation of more compact micellar aggregates when curcumin is present in the nanosystem.

Table 2. DLS data for free and CUR-loaded terpolymer micellar aggregates.

\begin{tabular}{|c|c|c|c|c|c|}
\hline Sample & CUR (\%) & Temperature $\left({ }^{\circ} \mathrm{C}\right)$ & $\begin{array}{l}\text { Intensity }{ }^{\text {a }} \text { (a.u.) } \\
\text { Free/Loaded }\end{array}$ & $\begin{array}{c}R_{h}{ }^{a}(\mathrm{~nm}) \\
\text { Free/Loaded }\end{array}$ & $\begin{array}{c}\text { PDI }^{\mathrm{a}} \\
\text { Free/Loaded }\end{array}$ \\
\hline \multirow{3}{*}{$\begin{array}{l}\text { PnBA }_{39}-b- \\
\text { PNIPAM }_{87-b-} \\
\text { PDMAEA }_{35}\end{array}$} & \multirow{2}{*}{10} & 25 & $5960 / 14,870$ & $83 / 71$ & $0.35 / 0.16$ \\
\hline & & 45 & $19,000 / 30,000$ & $54 / 73$ & $0.22 / 0.14$ \\
\hline & 20 & $\begin{array}{l}25 \\
45\end{array}$ & $\begin{array}{c}5960 / 17,450 \\
19,000 / 37,000\end{array}$ & $\begin{array}{l}83 / 61 \\
54 / 64\end{array}$ & $\begin{array}{l}0.35 / 0.13 \\
0.22 / 0.15\end{array}$ \\
\hline
\end{tabular}

a By DLS at $90^{\circ}$ angle.

As discussed in our previous work, in addition to its beneficial properties, curcumin can also be used as an imaging agent for bioimaging applications due to the strong endogenous fluorescence that it presents [46]. Given that, fluorescence spectroscopy measurements were performed on the CUR-loaded micellar aggregates. It has been proved that the solubility of curcumin in water $\left(4.2 \mu \mathrm{g} \mathrm{mL}^{-1}\right)$ is very low [43]. However, when entrapped in the hydrophobic environment of amphiphilic copolymer self-assemblies, its solubility increases significantly. CUR-loaded terpolymer micellar aggregates displayed an important increase in curcumin solubility, by a factor of $6\left(10 \mathrm{wt} \%\right.$ CUR, $\left.25 \mu \mathrm{g} \mathrm{mL}{ }^{-1}\right)$ and 12 times $\left(20 \mathrm{wt} \% \mathrm{CUR}, 50 \mu \mathrm{g} \mathrm{mL}^{-1}\right)$ compared to the case of water. In Figure 9, it can be observed that the peak of curcumin at $489 \mathrm{~nm}$ in THF shifted to $514 \mathrm{~nm}$ (10 wt\% CUR) and $504 \mathrm{~nm}(20 \mathrm{wt} \%$ CUR), respectively, in aqueous media. This shift is speculated to be due 
to the hydrophobic interactions that take place between CUR and the hydrophobic PnBA domains of the terpolymer. As far as fluorescence intensity is concerned, an interesting change occurred when temperature was increased at $45^{\circ} \mathrm{C}$. In both cases (i.e., for $10 \%$ and 20\% wt CUR), a significant increase in fluorescence intensity is observed, indicating that curcumin is arranged within the hydrophobic domains of the macromolecular assemblies according to the thermo-responsive structural reorganization of the copolymer. It is observed that by increasing the solution temperature, aggregates of greater mass are formed. Thus, CUR-loaded nanoparticles become more compact, which changes entrapped CUR spatial arrangements and interactions within the aggregates and ultimately results in higher fluorescence intensity.
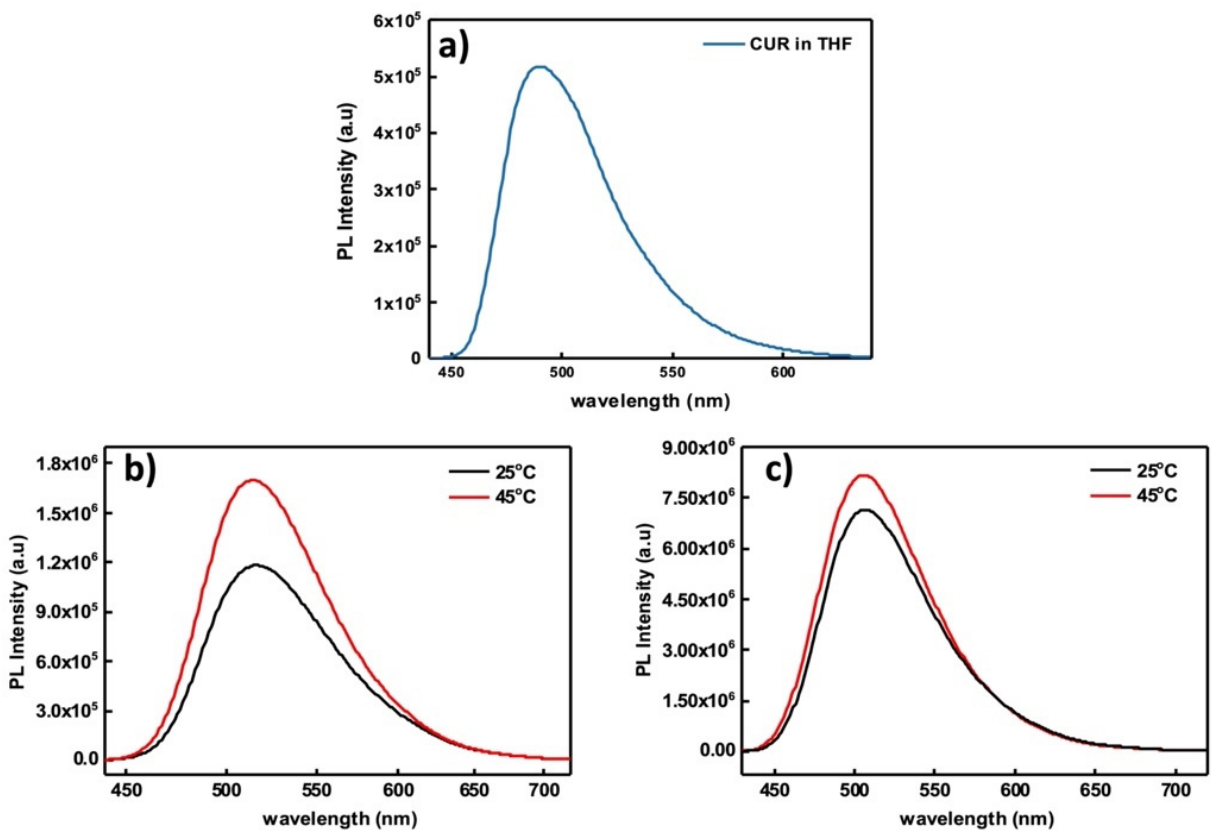

Figure 9. Fluorescence of CUR in THF $\left(c_{C U R}=100 \mu \mathrm{g} \mathrm{mL}^{-1}\right)(\mathbf{a})$, fluorescence of $10 \mathrm{wt} \%(\mathbf{b})$ and $20 \mathrm{wt} \%$ (c) CUR-loaded PnBA $_{39}-b$-PNIPAM $87-b$-PDMAEA 35 micellar aggregates.

The encapsulation procedure and the effect of temperature on the CUR-loaded aggregates is depicted in Scheme 3. The observed temperature dependence of fluorescence may be of potential utilization in bioimaging, e.g., in discriminating differences in temperature within cell or tissue environments.

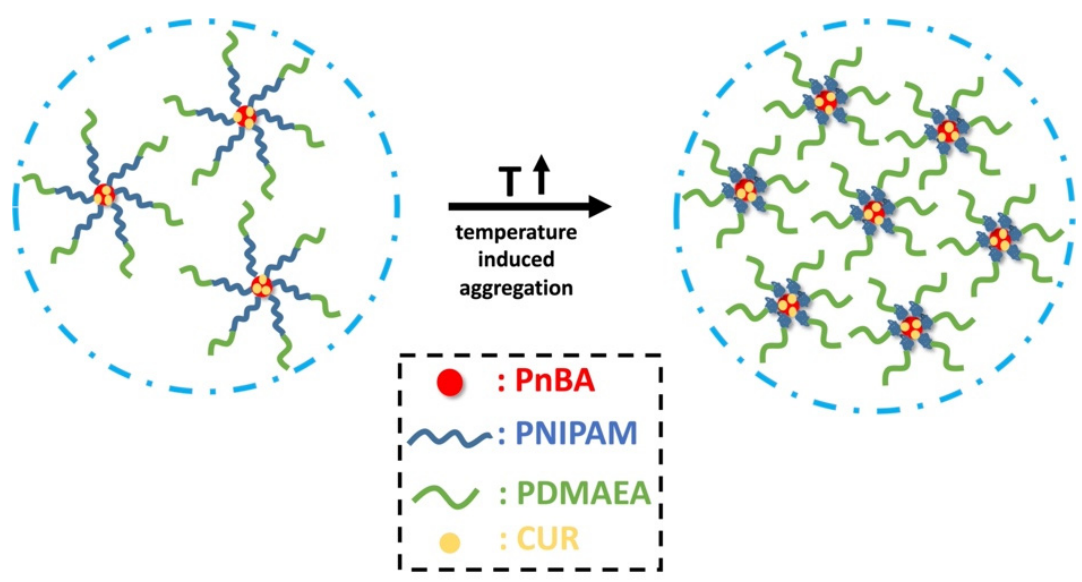

Scheme 3. Schematic illustration of CUR-loaded micellar aggregates and the effect of temperature. 


\section{Conclusions}

The complexation ability of PnBA- $b$-PNIPAM- $b$-PDMAEA and PnBA- $b$-PNIPAM$b$-QPDMAEA triblock terpolymers with DNA in aqueous solutions was studied. The electrostatic interactions between the quaternized terpolymers and DNA were found to be significantly stronger than the PnBA- $b$-PNIPAM- $b$-PDMAEA/DNA ones, due to the existence of permanent positive charges. The size of the PnBA- $b$-PNIPAM- $b$-PDMAEA/DNA polyplexes is larger (aggregate formation) and they exhibit increased responses to temperature variations because of the presence of the PNIPAM block. On the contrary, the polyplexes formed between PnBA- $b$-PNIPAM- $b$-QPDMAEA and DNA are smaller due to the higher solubility of the particular terpolymers in aqueous media because of the existence of more positive charges. These polyplexes do not present significant changes with temperature variations due to their stronger polyelectrolyte character. The PnBA- $b$ PNIPAM- $b$-PDMAEA terpolymers were also tested as nanocarriers for the encapsulation of the hydrophobic model drug curcumin in the hydrophobic PnBA cores of the formed micelles. The size of the drug-encapsulated nano-assemblies was smaller than the empty ones and this difference became larger at $45^{\circ} \mathrm{C}$, above the LCST of PNIPAM. Moreover, the endogenous fluorescence of curcumin exhibits a significant increase as the temperature increases above the LCST of PNIPAM, showing that this nanosystem can be promising for potential bioimaging applications.

Author Contributions: Conceptualization, S.P.; methodology, A.S. and D.S.; validation, S.P., A.S. and D.S.; data curation, A.S. and D.S.; writing-original draft preparation, A.S. and D.S.; writing-review and editing, S.P., A.S. and D.S.; visualization, A.S.; supervision, S.P. All authors have read and agreed to the published version of the manuscript.

Funding: This research is co-financed by Greece and the European Union (European Social FundESF) through the Operational Program "Human Resources Development, Education and Lifelong Learning" in the context of the project "Strengthening Human Resources Research Potential via Doctorate Research" (MIS-5000432), implemented by the State Scholarships Foundation (IKY).

Institutional Review Board Statement: Not applicable.

Informed Consent Statement: Not applicable.

Data Availability Statement: The data presented in this study are available on request from the corresponding author.

Conflicts of Interest: The authors declare no conflict of interest.

\section{References}

1. Pack, D.W.; Hoffman, A.S.; Pun, S.; Stayton, P.S. Design and Development of Polymers for Gene Delivery. Nat. Rev. Drug Discov. 2005, 4, 581-593. [CrossRef]

2. Sung, Y.K.; Kim, S.W. Recent Advances in the Development of Gene Delivery Systems. Biomater. Res. 2019, 23, 8. [CrossRef] [PubMed]

3. Thomas, T.J.; Tajmir-Riahi, H.-A.; Pillai, C.K.S. Biodegradable Polymers for Gene Delivery. Molecules 2019, 24, 3744. [CrossRef] [PubMed]

4. Lai, W.-F.; Wong, W.-T. Design of Polymeric Gene Carriers for Effective Intracellular Delivery. Trends Biotechnol. 2018, 36, 713-728. [CrossRef] [PubMed]

5. Nelson, C.E.; Gersbach, C.A. Engineering Delivery Vehicles for Genome Editing. Annu. Rev. Chem. Biomol. Eng. 2016, 7, 637-662. [CrossRef] [PubMed]

6. Guo, X.; Huang, L. Recent Advances in Nonviral Vectors for Gene Delivery. Acc. Chem. Res. 2012, 45, 971-979. [CrossRef] [PubMed]

7. Nayerossadat, N.; Maedeh, T.; Ali, P.A. Viral and Nonviral Delivery Systems for Gene Delivery. Adv. Biomed. Res. 2012, 1, 27. [CrossRef]

8. Dinçer, S.; Türk, M.; Pişkin, E. Intelligent Polymers as Nonviral Vectors. Gene Ther. 2005, 12, S139-S145. [CrossRef]

9. Kundu, P.P.; Sharma, V. Synthetic Polymeric Vectors in Gene Therapy. Curr. Opin. Solid State Mater. Sci. 2008, 12, 89-102. [CrossRef]

10. Pathak, A.; Patnaik, S.; Gupta, K.C. Recent Trends in Non-Viral Vector-Mediated Gene Delivery. Biotechnol. J. 2009, 4, 1559-1572. [CrossRef] 
11. Yin, H.; Kanasty, R.L.; Eltoukhy, A.A.; Vegas, A.J.; Dorkin, J.R.; Anderson, D.G. Non-Viral Vectors for Gene-Based Therapy. Nat. Rev. Genet. 2014, 15, 541-555. [CrossRef]

12. Navarro, G.; Pan, J.; Torchilin, V.P. Micelle-like Nanoparticles as Carriers for DNA and SiRNA. Mol. Pharm. 2015, 12, 301-313. [CrossRef]

13. Zhang, X.-X.; McIntosh, T.J.; Grinstaff, M.W. Functional Lipids and Lipoplexes for Improved Gene Delivery. Biochimie 2012, 94, 42-58. [CrossRef] [PubMed]

14. Cho, S.K.; Dang, C.; Wang, X.; Ragan, R.; Kwon, Y.J. Mixing-Sequence-Dependent Nucleic Acid Complexation and Gene Transfer Efficiency by Polyethylenimine. Biomater. Sci. 2015, 3, 1124-1133. [CrossRef]

15. Byrne, M.; Victory, D.; Hibbitts, A.; Lanigan, M.; Heise, A.; Cryan, S.-A. Molecular Weight and Architectural Dependence of Well-Defined Star-Shaped Poly(Lysine) as a Gene Delivery Vector. Biomater. Sci. 2013, 1, 1223-1234. [CrossRef] [PubMed]

16. Ivanova, E.; Dimitrov, I.; Kozarova, R.; Turmanova, S.; Apostolova, M. Thermally Sensitive Polypeptide-Based Copolymer for DNA Complexation into Stable Nanosized Polyplexes. J. Nanopart. Res. 2012, 15, 1358. [CrossRef]

17. Garrett, S.W.; Davies, O.R.; Milroy, D.A.; Wood, P.J.; Pouton, C.W.; Threadgill, M.D. Synthesis and Characterisation of PolyaminePoly(Ethylene Glycol) Constructs for DNA Binding and Gene Delivery. Bioorganic Med. Chem. 2000, 8, 1779-1797. [CrossRef]

18. Nisha, C.K.; Manorama, S.v.; Ganguli, M.; Maiti, S.; Kizhakkedathu, J.N. Complexes of Poly(Ethylene Glycol)-Based Cationic Random Copolymer and Calf Thymus DNA: A Complete Biophysical Characterization. Langmuir 2004, 20, 2386-2396. [CrossRef]

19. Crommelin, D.J.A.; Storm, G.; Jiskoot, W.; Stenekes, R.; Mastrobattista, E.; Hennink, W.E. Nanotechnological Approaches for the Delivery of Macromolecules. J. Control. Release 2003, 87, 81-88. [CrossRef]

20. De Smedt, S.C.; Demeester, J.; Hennink, W.E. Cationic Polymer Based Gene Delivery Systems. Pharm. Res. 2000, 17, 113-126. [CrossRef] [PubMed]

21. Skandalis, A.; Uchman, M.; Štěpánek, M.; Kereïche, S.; Pispas, S. Complexation of DNA with QPDMAEMA-b-PLMA-b-POEGMA Cationic Triblock Terpolymer Micelles. Macromolecules 2020, 53, 5747-5755. [CrossRef]

22. Giaouzi, D.; Pispas, S. Complexation Behavior of PNIPAM-b-QPDMAEA Copolymer Aggregates with Linear DNAs of Different Lengths. Eur. Polym. J. 2021, 155, 110575. [CrossRef]

23. Chroni, A.; Pispas, S. Hydrophilic/Hydrophobic Modifications of a PnBA-b-PDMAEA Copolymer and Complexation Behaviour with Short DNA. Eur. Polym. J. 2020, 129, 109636. [CrossRef]

24. Shim, M.S.; Kwon, Y.J. Stimuli-Responsive Polymers and Nanomaterials for Gene Delivery and Imaging Applications. Adv. Drug Deliv. Rev. 2012, 64, 1046-1059. [CrossRef] [PubMed]

25. Wei, M.; Gao, Y.; Li, X.; Serpe, M.J. Stimuli-Responsive Polymers and Their Applications. Polym. Chem. 2017, 8, 127-143. [CrossRef]

26. Pelton, R. Poly(N-Isopropylacrylamide) (PNIPAM) Is Never Hydrophobic. J. Colloid Interface Sci. 2010, 348, 673-674. [CrossRef] [PubMed]

27. Halperin, A.; Kröger, M.; Winnik, F.M. Poly(N-Isopropylacrylamide) Phase Diagrams: Fifty Years of Research. Angew. Chem. Int. Ed. 2015, 54, 15342-15367. [CrossRef]

28. Fliervoet, L.A.L.; van Nostrum, C.F.; Hennink, W.E.; Vermonden, T. Balancing Hydrophobic and Electrostatic Interactions in Thermosensitive Polyplexes for Nucleic Acid Delivery. Multifunct. Mater. 2019, 2, 024002. [CrossRef]

29. Türk, M.; Dinçer, S.; Yuluğ, I.G.; Pişkin, E. In Vitro Transfection of HeLa Cells with Temperature Sensitive Polycationic Copolymers. J. Control. Release 2004, 96, 325-340. [CrossRef]

30. Feng, G.; Chen, H.; Li, J.; Huang, Q.; Gupte, M.J.; Liu, H.; Song, Y.; Ge, Z. Gene Therapy for Nucleus Pulposus Regeneration by Heme Oxygenase-1 Plasmid DNA Carried by Mixed Polyplex Micelles with Thermo-Responsive Heterogeneous Coronas. Biomaterials 2015, 52, 1-13. [CrossRef]

31. Ma, Y.; Hou, S.; Ji, B.; Yao, Y.; Feng, X. A Novel Temperature-Responsive Polymer as a Gene Vector. Macromol. Biosci. 2010, 10, 202-210. [CrossRef] [PubMed]

32. Türk, M.; Dinçer, S.; Pişkin, E. Smart and Cationic Poly(NIPA)/PEI Block Copolymers as Non-Viral Vectors: In Vitro and in Vivo Transfection Studies. J. Tissue Eng. Regen. Med. 2007, 1, 377-388. [CrossRef]

33. Mao, Z.; Ma, L.; Yan, J.; Yan, M.; Gao, C.; Shen, J. The Gene Transfection Efficiency of Thermoresponsive N,N,N-Trimethyl Chitosan Chloride-g-Poly(N-Isopropylacrylamide) Copolymer. Biomaterials 2007, 28, 4488-4500. [CrossRef]

34. Calejo, M.T.; Cardoso, A.M.S.; Kjøniksen, A.-L.; Zhu, K.; Morais, C.M.; Sande, S.A.; Cardoso, A.L.; Lima, M.C.P.d.; Jurado, A.; Nyström, B. Temperature-Responsive Cationic Block Copolymers as Nanocarriers for Gene Delivery. Int. J. Pharm. 2013, 448, 105-114. [CrossRef]

35. Kanto, R.; Yonenuma, R.; Yamamoto, M.; Furusawa, H.; Yano, S.; Haruki, M.; Mori, H. Mixed Polyplex Micelles with Thermoresponsive and Lysine-Based Zwitterionic Shells Derived from Two Poly(Vinyl Amine)-Based Block Copolymers. Langmuir 2021, 37, 3001-3014. [CrossRef]

36. Haladjova, E.; Toncheva-Moncheva, N.; Apostolova, M.D.; Trzebicka, B.; Dworak, A.; Petrov, P.; Dimitrov, I.; Rangelov, S.; Tsvetanov, C.B. Polymeric Nanoparticle Engineering: From Temperature-Responsive Polymer Mesoglobules to Gene Delivery Systems. Biomacromolecules 2014, 15, 4377-4395. [CrossRef] [PubMed]

37. Ahmad, Z.; Shah, A.; Siddiq, M.; Kraatz, H.-B. Polymeric Micelles as Drug Delivery Vehicles. RSC Adv. 2014, 4, 17028-17038. [CrossRef] 
38. Ghezzi, M.; Pescina, S.; Padula, C.; Santi, P.; del Favero, E.; Cantù, L.; Nicoli, S. Polymeric Micelles in Drug Delivery: An Insight of the Techniques for Their Characterization and Assessment in Biorelevant Conditions. J. Control. Release 2021, 332, $312-336$. [CrossRef]

39. Zhang, Y.; Huang, Y.; Li, S. Polymeric Micelles: Nanocarriers for Cancer-Targeted Drug Delivery. AAPS PharmSciTech 2014, 15, 862-871. [CrossRef] [PubMed]

40. Bisht, S.; Feldmann, G.; Soni, S.; Ravi, R.; Karikar, C.; Maitra, A.; Maitra, A. Polymeric Nanoparticle-Encapsulated Curcumin ("nanocurcumin"): A Novel Strategy for Human Cancer Therapy. J. Nanobiotechnol. 2007, 5, 3. [CrossRef]

41. Hewlings, S.J.; Kalman, D.S. Curcumin: A Review of Its Effects on Human Health. Foods 2017, 6, 92. [CrossRef] [PubMed]

42. Tomeh, M.; Hadianamrei, R.; Zhao, X. A Review of Curcumin and Its Derivatives as Anticancer Agents. Int. J. Mol. Sci. 2019, 20, 1033. [CrossRef] [PubMed]

43. Liu, M.; Teng, C.P.; Win, K.Y.; Chen, Y.; Zhang, X.; Yang, D.-P.; Li, Z.; Ye, E. Polymeric Encapsulation of Turmeric Extract for Bioimaging and Antimicrobial Applications. Macromol. Rapid Commun. 2019, 40, 1800216. [CrossRef]

44. Skandalis, A.; Pispas, S. PH- and Thermo-Responsive Solution Behavior of Amphiphilic, Linear Triblock Terpolymers. Polymer 2018, 157, 9-18. [CrossRef]

45. Lowry, G.V.; Hill, R.J.; Harper, S.; Rawle, A.F.; Hendren, C.O.; Klaessig, F.; Nobbmann, U.; Sayre, P.; Rumble, J. Guidance to Improve the Scientific Value of Zeta-Potential Measurements in NanoEHS. Environ. Sci. Nano 2016, 3, 953-965. [CrossRef]

46. Selianitis, D.; Pispas, S. P(MMA-Co-HPMA)-b-POEGMA Copolymers: Synthesis, Micelle Formation in Aqueous Media and Drug Encapsulation. Polym. Int. 2021. [CrossRef] 